Loyola University Chicago, School of Law LAW eCommons

Faculty Publications \& Other Works

2009

\title{
War's Legacy in International Investment Law
}

James T. Gathii

Loyola University Chicago, School of Law, jgathii@luc.edu

Follow this and additional works at: http://lawecommons.luc.edu/facpubs

Part of the International Law Commons

Recommended Citation

James T. Gathii, War's Legacy in International Investment Law, 11 Int'l Comm. L. Rev. 353 (2009).

This Article is brought to you for free and open access by LAW eCommons. It has been accepted for inclusion in Faculty Publications \& Other Works by an authorized administrator of LAW eCommons. For more information, please contact law-library@luc.edu. 


\title{
War's Legacy in International Investment Law
}

\author{
James Thuo Gathii* \\ Associate Dean for Research and Scholarship, Governor George E. Pataki Professor of \\ International Commercial Law, Albany Law School, Albany, NY, USA
}

\begin{abstract}
This article discusses the role war has played in shaping the rules of international investment law from the late nineteenth century. At the end of the nineteenth century and the beginning of the twentieth century, the move towards institutions, such as arbitration forums, and rules as an alternative to the use of force gave new impetus to the growth of international commercial law and related institutions. These rules and institutions represented the hope that the use of force would be eclipsed as States moved forward towards more cooperative, consensual and non-coercive mechanisms of dispute settlement. Capital-importing states in Latin America however became acutely aware that these institutions and rules did not completely erase the coercive and uneven relations they had with capital-exporting states. In era after era of reformism from the Calvo era, to the NIEO and to the era in opposition to neo-liberal economic governance, capital-importing States have continued to resist and sometimes adapt to the coercive realities of the rules of international investment law. The article begins by tracing the origin of the Drago doctrine as a response to the practice of European states that engaged in aggression and conquest against militarily and economically weaker Latin American states as a means of collecting debts owed to their citizens. It then shows that while the denouement of forcible measures to resolve contract debt was overstated by early twentieth century international lawyers, international law nevertheless provided avenues for dispute settlement outside the use of force in international commercial relations. Thus while protecting commerce from the scourge of war was a primary inspiration for the post-Second World War international economic order, the author shows how war has nevertheless continued to be an animating factor for former colonies particularly with regard to their State responsibility for war damage in the context of foreign investment.
\end{abstract}

\section{Keywords}

war; international law; international investment law; Drago Doctrine; Calvo Doctrine; state responsibility for war damage; bilateral investment treaties; investor-State arbitration

\section{Introduction}

Recent scholarship has celebrated the peaceful consequences of regimes of the international economic order. 'The advent of the Bretton Woods institutions and

*) This article is a version of a chapter in my forthcoming book, James Gathii, War, Commerce and International Law (Oxford University Press, 2010). Thanks to Ibironke Odumosu for her comments on an earlier draft.

1) Symposium, 'Trade as Guarantor of Peace, Liberty and Security: The Role of Peace in the Bretton Woods Institutions', 20 Am. Univ. L. Rev. 1113 (2005); Donald Markwell, John Maynard Keynes and International Relations: Economic Paths to War and Peace (2006); For other views, see 'Symposium, War 
the United Nations were in fact, institutional responses to the World War II that embodied a set of goals and principles as alternatives to resolving conflict by war. It is not therefore surprising that the pragmatism and functionalism of the postWorld War Il period also regarded these institutions as a victory over the dark forces and passions that led to the outbreak of World War II.

Rules and institutions of international trade and investment also provide alternatives to the role of territorial conquests as ways of facilitating access to resources in formerly colonized countries needed by multinational firms. In addition, as shown in this paper, rules of international investment law and arbitral forums were seen as alternatives to the forcible collection of debts. In short, although territorial conquest in the nineteenth century facilitated the extraction of mineral and other resources from poor countries, in the twenty-first century international legal regimes ensure their continued nonviolent access.

This article explores the role war has played in the formation and consolidation of rules and institutions of international investment law. In so doing, this paper shows how notwithstanding the guarantees of self-determination, equality of States and permanent sovereignty over natural resources, private international law to date continues to guarantee regimes of economic governance that protect rights of alien investors often at the expense of the former colonies. This continuity has an uncanny resemblance to the era when conquest and war were permissible means of international economic interaction.

The article begins by discussing the origins of the Drago doctrine in the Venezuelan blockade of 1902 by Great Britain, Germany, and Italy. It then traces the origins of binding international arbitration to this incident. Various efforts to address problems arising in commercial disputes between capital importing and capital exporting countries such as the Calvo clause and the New International Economic Order are then addressed. There is an examination of how arbitral forums have resolved cases involving State responsibility for war destruction. The last major section of the paper reflects on how the resolution of war destruction cases tells us about the move from forcible to unequal economic relations between capital importing and exporting States.

\section{The Relevance of War in Shaping Rules of International Economic Governance}

This section examines continuities and discontinuities of rules of international economic governance particularly as they relate to issues surrounding war from the colonial to the postcolonial era. Although protecting commerce from the

and Commerce', 31 Brook. J. Intl L. (2006); Nathaniel Berman, 'Economic Consequences, Nationalist Passions: Keynes, Crisis, Culture and Policy', 10 Am. Univ. J. Intl L. and Pol'y, 619 (1995); Padideh Alai, Tomer Broude and Colin B. Picker (Eds.) Trade as the Guarantor of Peace, Liberty and Security? Critical, Historical and Empirical Perspectives, (Am. Soc. Int'l Law Press, 2006), p. 97. 
scourge of war was a primary inspiration for the post-World War II international economic order, war was also an animating factor for former colonies in designing new rules of international economic governance. The relevance of war for postcolonial economic governance, particularly in the nineteenth century for newly independent Latin American countries, is often understated or simply regarded as an instance of economic nationalism.

Two of the best examples of the influence of war in shaping rules of international economic governance is the nineteenth-century Latin American innovation required in contracts between foreign investors and nationals and Latin American governments, known as the Calvo clause and the Drago doctrine. The origins of the Calvo clause arose as a response to the nineteenth-century practice of European States that engaged in aggression and conquest against militarily and economically weaker Latin American States as a means of collecting debts owed to their citizens. The Drago doctrine arose from a 1902 warlike blockade of Venezuela by Great Britain and Germany with the diplomatic support of Italy. Following unrest and turmoil in Venezuela, the Venezuelan government refused to settle claims it owed to bondholders from Great Britain, Germany, and Italy. Venezuela proposed that it would only settle those claims in a Commission comprised of Venezuelans. ${ }^{2}$ This blockade quickly coerced Venezuela into compliance. ${ }^{3}$

In a letter dated December 29, 1902, the Venezuelan Secretary of Foreign Affairs, Luis M. Drago, protested the "collection of loan by military means" for its inconsistency with Venezuela's sovereignty. He argued that forcible collection of loans not only amounted to a form "territorial occupation" of Venezuelan territory, but also signified the "suppression or subordination" of Venezuela to these creditor nations. ${ }^{4}$ The letter then stated what became known as the Drago doctrine: "That the public debt cannot occasion armed intervention nor even the actual occupation of the territory of American nations by a European power."

The Drago doctrine was therefore both a nonintervention principle as well as a statement of the special nature of public bonds and loans taken by States. It was a noninterventionist principle because it was aimed against armed interventions and occupation of debtor States by creditor States. It was a statement of the special nature of bonds and loans borrowed by governments because the doctrine was based on distinguishing the kinds of remedies that were available to creditors

\footnotetext{
2) Luis M. Drago and H. Edward Nettles, 'The Drago Doctrine in International Law and Politics', 8 Hisp. Am. Hist. Rev. 204 (1928). There is some controversy regarding the purpose of this blockade. Some suggested it was not so much to protect bond-holder rights as to protect the lives, liberty, and property of British subjects, id. at 205-206. However, the forcible collection of debts was undoubtedly the primary reason for the Drago doctrine.

3) Id.

4) Id. at 209.

5) Id. For a full exploration of this, Luis M. Drago, 'State Loans in their Relation to International Policy', Am. J. Intl L. 692-726 (1907).
} 
when the borrower was a private individual rather than the government. According to Drago, a lender who lends to a sovereign knows that "no proceedings for the execution of a judgment may be instituted or carried out against it." The Drago doctrine is therefore closely associated with the now obsolete theory of absolute sovereign immunity in commercial transactions involving sovereigns. ${ }^{7}$ I will return to this point below to show how the now obsolete rule of absolute immunity enunciated in the Drago doctrine represented an effort to move from the justifiable use of force in the collection of sovereign debt toward a juridical framework in which the use of force was impermissible.

The Drago doctrine was an effort aimed at finding juridical proscription of the use of force in the economic relations between militarily weak debtor Latin American countries, on the one hand, and militarily powerful European States, on the other. Law for Latin American countries represented the best hope for restraining the use of force against them by countries with more military power than they had. In fact, Drago specifically argued against the use of violence as inapplicable to Venezuela because it involved conquest. ${ }^{8}$ In so doing, he was advocating against the views of scholars of international law of his day such as W.E. Hall who held the view that States had the right to engage in forcible interventions to collect public debt. ${ }^{9}$ In fact, U.S. Secretary of State Elihu Root, while asserting that the use of armed forces by a State for the collection of ordinary contracts debts on behalf of its citizens was regrettable, left open the possibility that it was justifiable to use force over nonpayment of public debts "when accompanied by such circumstances of fraud, wrong-doing or violation of treaties."10

When the Second Hague Conference met in 1906 and negotiated the Convention Respecting the Limitation of the Employment of Force for the Recovery of Contract Debts, the contracting parties agreed not "to have recourse to armed force for the recovery of contract debt claimed from the Government of one

\footnotetext{
6) Drago, supra note 5, as quoted in Drago and Nettles, supra note 2, at 211.

7) Today, it is generally recognized that foreign states are not immune from jurisdiction in a judicial forum when they have engaged in commercial conduct equivalent to that which private actors engage in. There is therefore no absolute immunity for acta jure imperii, (acts of state of a commercial nature) because they will be regarded as acta jure gestionis thereby subjecting the State to suit. See Sienho Yee, Towards an International Law of Co-Progressiveness, pp. 280-85 (2004). See also Robert Wai, 'The Commercial Activity Exception to Sovereign Immunity and the Boundaries of Contemporary Legalism', in Craig Scott (Ed.), Torture as Tort: Comparative Perspectives on the Development of Transnational Human Rights (2001) p. 213.

8) Drago, supra note 5 , at 725.

9) W.E. Hall, International Law (1880); Thomas H. Lee, 'The Safe-Conduct Theory of the Alien Tort Statute', 106 Colum. L. Rev. 830, 821 (2006) also argued that "[u]nder traditional state-based principles of international law - i.e., those from the eighteenth to the early twentieth centuries - the safe conduct promise was enforceable through the offended sovereign's right to make war in the event of a breach," $i d$. However, see Amos S. Hershey, 'Hague Convention Restricting the Use of Force to Recover on Contract Claims', 1 Am. J. Int'l L. 78 (1908)

10) Root's instructions to the 1906 Hague Conference, as cited in Drago and Nettles, supra note 5 , at 218 .
} 
country by the Government of another country as being due to its nationals."' However, consistent with Root's reservation that the use of armed force was unjustifiable in all cases, a proviso to this prohibition in the Hague Convention provided that use of force would be permissible where a "debtor state refuses or neglects to accept an offer of arbitration, or after accepting the offer, prevents any compromise from being agreed upon, or, after the arbitration, fails to submit to the award." 12

In 1957, the International Court of Justice endorsed this interpretation in the Case of Certain Norwegian Loans when it noted that the Convention Respecting the Limitation of the Employment of Force for the Recovery of Contract Debts, although not requiring compulsory arbitration over contractual debts, imposed an obligation "that an intervening power should not have recourse to force before it had tried arbitration." 13 As Judge Sir Hersch Lauterpacht noted in his separate opinion in this case, ${ }^{14}$ Article 52(2) of the Hague Convention for the Pacific Settlement of International Disputes gave the Permanent Court of Arbitration competence to settle by agreement disputes "arising from contract debts claimed from one Power by another Power." 15 Sir Lauterpacht interpreted the recognition of the contract debts among sovereigns for arbitration as an indirect recognition that controversies relating to debts between States were "suitable for settlement by reference to international law." 16 In other words, international law came to be regarded as a substitute for war as means of collecting contract debt. Indeed, as President Roosevelt stated in support of the provision seeking to limit the use of force in the collection of debts in the Hague Convention Respecting the Limitation of the Employment of Force for the Recovery of Contract Debts "such a provision would have prevented much injustice and extortion in the past." 17 International law was clearly being seen as an antidote to forcible measures.

Clearly then, during the negotiations and subsequent recognition of the principle of pacific settlement of disputes in the 1906 Hague Conference, the right claimed by States, particularly in the late nineteenth and early twentieth centuries, to collect debt by forcible means was sought to be limited under rules of international law. Although the early twentieth-century prohibition of the use of force to collect debts in the Hague Conventions was only partial, it represented an important step toward the eventual prohibition of the use of force between

11) Convention Respecting the Limitation of the Employment of Force for the Recovery of Contract Debts, Oct. 18, 1907, Art. 1, 36 Stat. 2241, T.S. 537 [hereinafter Hague Regulations on Debt Recovery].

12) $I d$.

13) Case of Certain Norwegian Loans (Fr. v. Nor.) 1987 I.C.J. (July 6).

14) Id. (Lauterpacht, separate opinion).

15) Hague Convention for the Pacific Settlement of International Disputes, Oct. 18, 1907, 36 Stat. 2199, T.S. 233.

16) Case of Certain Norwegian Loans (Lauterpacht, separate opinion), at 38933.

17) Cited in James Brown Scott, 'The Work of the Second Hague Peace Conference', 1 Am. J. Int'l L. 15 (1908). 
States in the United Nations Charter. ${ }^{18}$ For my purpose here, the move toward arbitration and away from the use of force to enforce contract debts shifted the concerns of weak, mostly non-Western countries from the fear of forcible interventions to the bias against them in the rules, processes, and outcomes of arbitral forums. ${ }^{19}$ These countries saw these biases as a reflection of their unequal bargaining power vis-à-vis the wealthy countries and their giant multinational firms on which they depended on for finance, technology, and trade.

Thus, whereas the principle of the pacific settlement of disputes and the partial rejection of the use of force to enforce debt contracts were important advances in the relations between capital-exporting and capital-importing States, peaceful settlement of disputes through forums such as arbitration did not necessarily eviscerate the coercion that was characteristic in contractual relations between economically stronger and weaker parties. In addition, without an explicit prohibition on the use of force, there was still the possibility that armed force could still be used in the collection of public debts after the Hague Conventions came into force. Without such an explicit prohibition on the use of force, defaulting States therefore lived under the threat that capital-exporting States might wage war against them to enforce their rights, rather than to submit to compulsory or obligatory arbitration as proposed in the course of the First and Second Hague conferences. ${ }^{20}$ Thirteen of what were termed the "small powers" at the Second Hague Conference who were likely to be subject to forcible collection of debt,

18) Article 2(4) of the United Nations Charter, which is regarded as a jus cogens norm under international law provides that "[a]ll members, shall refrain in their international relations from the threat or use of force against the territorial integrity or political independence of any state, or in any other manner inconsistent with the Purposes of the United Nations." In addition, UN General Assembly Resolution 3314(XXIX) of 1974, on the Definition of Aggression defined aggression as "the use of armed force by a State against the sovereignty, territorial integrity or political independence of another State, or in any other manner inconsistent with the Charter of the United Nations," (Art. 1) and further defined the "blockade of ports or coasts of a State by armed forces of another state" (Art. 3(c)) as constituting aggression. Notably, the Drago doctrine arose precisely out of this kind of a blockade. Article 5 of the Aggression Resolution provides that "No consideration of whatever nature, whether political, economic, military or otherwise, may serve as a justification for aggression," $i d$. In addition, it is notable that although the use of force "must be avoided as far as possible" when it is inevitable "it must not go beyond what is reasonable and necessary under the circumstances," M.V. Saiga No. 2, (Saint Vincent and the Grenadines v. Guinea), Vol. 10 Int'l Tribunal L. Sea Rep. 155 (1999).

19) One of the best articulations of this bias is Amr Shalakany, 'Arbitration and the Third World: A Plea for Reassessing Bias under the Specter of Neo-Liberalism', 41 Haru. Intl L.J. 419 (2000); see also, M. Sornarajah, International Commercial Arbitration: The Problem of State Contracts (Longman, London, 1990).

20) Amos S. Hershey, 'Hague Convention Restricting the Use of Force to Recover on Contract Claims', $1 \mathrm{Am}$. J. Int'l L. 78 (1908), "arguing that every State which considers itself aggrieved enjoys the sole right to decide the redress which it shall exact and, also, whether in a given case it has exhausted all peaceful remedies it should pursue in order to secure redress. The use of force is a recognized legal remedy by which states may settle their differences." Id. at 85 (emphasis added). But see Michael Tomz, Reputation and International Cooperation: Sovereign Debt Across Three Centuries (Princeton University Press, Princeton, NJ, 2007) (arguing that the use of force to collect Venezuelan debt was exceptional and not motivated solely by default). 
supported "obligatory arbitration." By contrast, the big powers, such as the United States and Great Britain, sought to reserve their right to protect what they termed their "vital interests, independence and honor" through the use of force. ${ }^{21}$

Today, high transaction costs, as well as prohibitions on the use of force, have reduced, if not entirely eliminated, the resort to war for the collection of contract debt. ${ }^{22}$

In addition, wars for debt collection came to be discredited as between "civilized nations," but also against "small and weak nations." The use of force to collect private debts against small and weak nations came to be regarded as a "violation of the doctrine of international law that independent nations should stand upon a footing of equality." 23

As the use of force to collect debt fell into disuse, and the liberalization of financial markets grew in pace from the nineteenth century and accelerated even more in the twentieth century with the removal of obstacles to the flow of finance across national boundaries, the enforcement costs of contract debt became "as high if not higher than in the nineteenth century." ${ }^{24}$ The enormous debt owed to capital-exporting States by capital-importing States has therefore unsurprisingly been a major theme in international economic relations at the end of the twentieth century and the beginning of the twenty-first century. ${ }^{25}$

Suffice it to say, the declining significance of the use of force to collect contract debt merely relocated from the battlefield to arbitral and judicial forums the same concerns that inspired the Drago doctrine. The belief of early international lawyers, including Luis Drago, was that rules and institutions of international law were neutral and apolitical alternatives to the use of force would soon be under

21) William I. Hull, 'Obligatory Arbitration and the Hague Conferences', 4 Am. J. Int'l L. 737 (1908).

22) Charles Lipson, Standing Guard: Protecting Foreign Capital in the Nineteenth and Twentieth Centuries (University of California Press, Berkeley, CA, 1985). Addressing the use of forcible interventions to address bond defaults notes, Britain's naval capacity and its diplomatic network were formidable. Direct and frequent interventions promised immediate and tangible gains. Yet such a course was both risky and costly. It was costly, even in the short run, if the desired results could be won diplomatically. It was risky in the long run because direct interventions undermined the basis of local political authority and social control. British policy in Latin America demonstrated a clear understanding of these alternatives. It was based on the idea that it was cheaper to hear the immediate costs of bond defaults than to risk sabotaging local governments by frequent interventions. Id. at $44-45$ (emphasis added).

Peter Liberman, 'The Spoils of Conquest', 18 Intl Security 125, 150 (1993) (also argues that the costs of imperial adventures, among other factors such as nationalism, now outweigh the benefits of such adventures). See also Stephen Brooks, 'The Globalization of Production and the Changing Benefits of Conquest', 43 J. Conflict Resol. 646-70 (1999) (arguing that the central role of foreign direct investment in contemporary globalization may allow governments to substitute that instrument of external economic influence for older instrument of conquest).

23) 'Wars for Debt Collection', N.Y. Times, May 12, 1903, at 8.

24) Gerald Epstein, 'International Capital Mobility and the Scope for National Economic Management', in Robert Boyer and Daniel Drache (Eds.), States Against Markets: The Limits of Globalization, (Routledge, 1996), pp. 211-224, 217.

25) World Bank, Can Africa Claim the 21st Century? (2000) (noting the significance of debt and aid dependence as one of the major constraints on Africa's development prospects in the twenty-first century). 
scrutiny. Influenced by the classical legal thinking of their time, these lawyers believed that there were only two ways of achieving harmony or reconciliation through either force or law. ${ }^{26}$ Arbitration for them was an example of a larger set of voluntary and consensual processes that States could use to resolve conflicts rather than resorting to war. ${ }^{27}$ These lawyers celebrated international law as a noncoercive solution through which problems, domestic and international, could be cooperatively and beneficially resolved. ${ }^{28}$ Not only did this early thinking of international law therefore assume a harmony of interests that could be worked out impartially if not scientifically, but it also denied that "coercion was the basis of [international] legal efficacy." 29

This early faith in the neutrality and impartiality of the law denied the role of power and coercion in international relations and institutions ${ }^{30}$ and in rules of law. ${ }^{31}$ Rules of law, after all, are more often than not politics by other means. For example, gross inequalities and disparities of bargaining power in contracts between indebted sovereign nations and financially sophisticated multinational firms could very well lead to the conclusion that such contracts are no more than a "power order" 32 than consensually bargained deals. Thus, while poor countries now enjoy the autonomy to freely enter into commercial contracts, they continue to be concerned about the reciprocity or underlying fairness of these deals. ${ }^{33}$ For

26) Joseph Beale, an early classicist for example argued that there "are only two methods of reconciliation: force, and law. Either the will of the physically strongest, or of the mentally alertest, must prevail - the way of the beast; or conflicting wills must be restrained by law - the way of organized human society," cited in Jonathan Zasloff, 'Abolishing Coercion: The Jurisprudence of American Foreign Policy in the 1920 's', 102 Yale L.J. 1689, 1698 (1993).

27) See Richard H. Steinberg and Jonathan M. Zasloff, 'Power and International Law' (Centennial Essay) $100 \mathrm{Am}$. J. Int'l L. 66 (2006).

28) Id. at 69. See also Robert Wai, 'Transnational Liftoff and Juridical Touchdown: The Regulatory Function of Private International Law in an Era of Globalization', 40 Colum. J. Transnatl L. 209 (2002) (examining the benefits and challenges of international cooperation).

29) Steinberg and Zasloff, supra nore 26, at 68; Zasloff, supra note 25.

30) Steinberg and Zasloff, supra note 26 , at 72 (discussing realism in international law and international relations).

31) Duncan Kennedy, 'The Stakes of Law, or Hale and Foucault!', XV Leg. Studies Forum 327 (1991) (arguing in part that early conservative economic rhetoric justified the existing capitalist system as being based on freedom in contrast to socialism, which replaced freedom with state coercion and how realists showed that freedom or agreement was a product of coercion "by which they meant that neither party got what the wanted (the whole joint product) and that each had the experience of being 'forced to settle for less," id. at 328.

32) Roberto Mangabeira Unger, The Critical Studies Movement, 70 (1983).

33) Michael J. Sandel, Liberalism and the Limits of Justice (1982) notes that "Unlike obligations voluntarily incurred, obligations arising under the ideal of reciprocity must presuppose some criterion of fairness independent of contract, some way in which the objective fairness of an exchange may be assessed," id. at 107-08. See also, Nagla Nassar, Sanctity of Contracts Revisited: A Study in the Theory and Practice of LongTerm International Commercial Transactions (1995), arguing that "If as claimed by classical theorists, legal rules are merely concerned with resource allocation, then the unfairness of the classical rule in denying adjustment is somewhat but not completely, justifiable. From a societal perspective, the adjustment rule, according to the classical model, is considered inefficient, for it wastes society's revenue on an unnecessary 
them, simply having an agreement, institution or process is insufficient to establish its fairness.

That is why, in arbitral forums, rules of private international law much like the right to use force to collect debt were challenged by poor countries as "furthering colonial inequalities" ${ }^{34}$ very much like the wars for debt collection. The Calvo clause, which I will turn to shortly, was an early effort to reform private international law to address such inequalities and the concerns of Latin American States.

The upshot of my argument so far is that the legalization and institutionalization of international commercial disputes did not end the concerns about the exercise of coercion and power by capital-exporting over capital-importing States. Perhaps nothing illustrates better the legalization and institutionalization of international commercial disputes than the arbitral proceedings that arose from the Allied blockade (British, German, and Italian), of Venezuela that inspired the Drago doctrine in the first place. Having set aside 30 percent of all customs receipts of two Venezuelan ports to settle the claims of all her creditors, the Allied powers demanded preferential payment over all other creditor nations. ${ }^{35}$ Venezuela and the Allied powers decided, as a condition for lifting their blockade, that they would accept arbitration over the question of preferential treatment before the Permanent Court of Arbitration in the Hague. ${ }^{36}$ For Venezuela, the arbitration proceedings in this case were superior to enforcement of the contract claims by forcible means. Yet, in many ways Venezuela's agreement to arbitral proceedings was in no small way influenced by the vastly superior military/naval power of the allied forces while Venezuela was still subject to the allied powers blockade. ${ }^{37}$ So powerful were these blockading powers that they used the arbitral

reallocation of resources.... The validity of the above argument is very doubtful. First, it is misleading to assume that society has no interest in the equitable reallocation of resources... Secondly, arguing that the main concern of the rule of law is to maximize wealth is a misleading proposition. Laws have been created ... to establish social peace and promote exchange... This is particularly true of international society where actors come from different societies at different levels of economic development and with different legal rules.... In the absence of a strong institutional organization, actors need to be assured that their interests will not be sacrificed because of an event they could not have known about or controlled." Id. at 233-34.

34) Antony Anghie, Imperialism, Sovereignty and the Making of International Law 239 (2005). For a different view, see Duncan Kennedy, 'Distributive and Paternalist Motives in Contract and Tort Law, with Special Reference to Compulsory Terms and Unequal Bargaining Power', 41 Md. L. Rev. 563, 580 (1982) (arguing that the "real problem with freedom of contract is that neither its principles, nor is principles supplemented by common moral understanding, nor its principles supplemented by historical practice, are definite enough to tell the decision maker what to do when asked to change or even just to elaborate the existing law of agreements").

35) The Venezuelan Preferential Case (Germany, Great Britain, Italy, Venezuela et al.), in IX Reports of International Arbitral Awards, 103 (United Nations, ed., 1904).

36) Protocol between Germany and Venezuela for the Reference of Certain Questions to the Permanent Court of Arbitration at the Hague (signed ar Washington, May 7, 1903) in International Arbitral Awards, supra note 34, at 105-06; Protocol between Great Britain and Venezuela Relating to the Settlement of the British Claims and Other Matters (signed Washington, Feb. 13, 1904) in International Arbitral Awards, supra note 34.

37) See 'In Fear of the Hague: Every Effort Making to Settle Venezuela Case in Washington', N.Y. Times 
process, against Venezuela's protestations, to win a right to preferential treatment above all other creditors. ${ }^{38}$ In fact, not only did the Permanent Court of Arbitration grant the blockading powers the right to preferential treatment, but it also rejected Venezuela's argument on jurisdictional grounds to decide whether the allied powers had exhausted all orher remedies prior to engaging in the use of force. ${ }^{39}$

In the next section, I will examine how the legalization and institutionalization of international commercial disputes set the stage for more skirmishes between these countries. The debates about the Calvo clause represent one early episode in these disagreements between capital importing and capital exporting States.

\section{The Calvo Clause and its Progeny}

As we noted above, the Calvo clause proclaimed the sovereign equality of Latin American countries with more powerful States, and their independence from diplomatic interference with regard to matters arising out of contractual relations. ${ }^{40}$ In effect, both the Calvo clause and the Drago doctrines represented efforts by the newly independent Latin American countries to overcome the unequal economic relations they had with capital-exporting States.

The Calvo clause required foreign investors to submit to the remedies available within the judiciaries of Latin American countries, rather than to be governed by rules of their home countries or rules of international law. It was designed to circumvent capitulation treaties, which were imposed by capital-exporting States requiring capital-importing States to protect the rights of alien investors through the use of the law of the capital-exporting State. The Calvo clause, in essence, required foreign investors to forfeit the option of pursuing alternative remedies, such as diplomacy or war to collect on their debts. Under the Calvo clause, foreign investors had the same degree of protection as domestic investors. It was a rule of equal treatment in the protection of foreign and national investors of Latin American countries.

As such, the Calvo clause was predicated on the view that there did not exist a universal or "international standard of justice" that alien investors were entitled to under customary international law. Instead, under the Calvo clause foreign investors were entitled to exactly the same remedies as domestic investors. Domestic, rather than international law, was the source of rights for foreign investors. Only where a denial of justice occurred, under some Latin American Calvo

Feb. 5, 1903, at 1 (noting in part that negotiations were proceeding and that referring the matter to the Hague would prolong the blockade and would be of no good).

38) The Venezuela Preferential Case: Award of the Tribunal of Arbitration, in IX Reports of International Arbitral Awards supra note 34, at 107-10.

39) Id. at 108.

40) M.R. Garcia-Mora, 'The Calvo Clause in Latin American Constitutions and International Law', 33 Marg. L. Rev. 4, 205-06 (1950). 
clauses, could foreign investors resort to rules of international law for remedies. A violation of the Calvo clause resulted in the termination of the rights that a foreign investor had under the contract in question. As a Mexican jurist argued in 1944, the purpose of the Calvo clause was to prevent foreigners from using the diplomatic protection of their countries as "an instrument of oppression... by strong States against weak ones." ${ }^{1}$

\section{African and Asian Challenges to International Economic Law and Governance}

If the nineteenth-century system of capitulations and forcible enforcement of contractual rights was rejected by Latin American countries, neither was the postWorld War II regime of international economic law and governance embraced without severe reservations by newly independent countries of Asia and Africa. The best example of the objections these countries had to the old regime of international economic governance was the clean slate theory. States that adhered to this theory argued that they should be freed from having to assume obligations that legitimized colonial conquests and acquisitions upon independence. The Nyerere doctrine, for example, advocated that countries should be able to select only those treaty commitments that best comported with their newly acquired sovereignty. ${ }^{42}$

However, as Antony Anghie has shown, efforts by these newly independent countries to undo treaty commitments and customary international law rules in the international investment area were strongly challenged by capital-exporting States. ${ }^{43}$ Several arguments were deployed against the clean slate theory and the Nyerere doctrine. One of the primary means by which the continuity of prior treaty and customary rights was assured was through the assertion of the doctrine of State succession. Rules of State succession require new States to undertake treaty and other rights assumed by the old State. ${ }^{44}$ Under this doctrine, it is irrelevant how those treaties were procured or indeed, how illegitimate and unequal the commitments in these treaties and agreements were.

Developed countries and their supporters also invoked the doctrine of acquired rights, under which rights that preexisted the independence of the new States were required to be upheld. Whereas newly independent countries argued in

41) Id.

42) E.E. Seaton and S.E. Maliti, Tanzania Treaty Practice (1973). See also M. Bedjaoui, Towards $A$ New International Economic Order (1979), 110 (arguing that international law could not easily assume the task of transforming international relations because it had been "confined to protecting a type of international relations not yet purged of inequality and imperialism").

43) Antony Anghie, Imperialism, Sovereignty and the Making of International Law (2005) 196, $226-244$.

44) Vienna Convention on Succession of States in Respect of States Property, Archives and Debt, Apr. 8, 1983, Arts. 32-36 (1983) 31:1 Select Documents on Int'l Aff. 10 (1983) [hereinafter Vienna Convention] (establishing the survival of State debts). 
favor of revising treaty commitments and mineral concessions that they had played no part in making while they were under colonial rule, developed countries argued that they were seeking to unilaterally modify these commitments, inconsistent with the principle of pacta sund servanda. Indeed, several international law jurists from developed countries ${ }^{45}$ argued that changing these acquired rights or the customary international law rules that guaranteed the rights of alien investors would result in unraveling the very international legal order that had brought these countries into existence. One such jurist argued that, in so far as the rules newly independent countries wanted to repudiate were customary international law, they could only have done so when the rules were in formation. ${ }^{46}$ Because these rules were already in force, they had been in formation long before the independence of African and Asian countries. ${ }^{47}$

In the 1970 s, developing countries sought to change various rules of international economic governance that they perceived as prejudicial to them through the legislative agenda of the United Nations General Assembly. They argued that rules of State responsibility gave them jurisdiction to regulate foreign investors within their territory, to enable them to regulate the conditions of under which these investors could enter into their economies, and in particular the jurisdiction to: exclude foreign investors from certain sectors of their economies, as well as to regulate the permissibility and scope of repatriating capital and profits and the conditions under which technology could or could not be transferred to their economies. As in the Calvo clause era, these countries argued that international law was only valid in so far as it required these newly independent countries to treat foreign and domestic investors similarly. ${ }^{48}$

These efforts included the 1970s initiative to inaugurate a New International Economic Order (NIEO). Using their majorities in the United Nations General

45) Sir Humphrey Waldock, 'General Course on Public International Law', 106 Rec. de Cours 1, 49-53 (1962-II). This rule is also reflected in Restatement (Third) of Foreign Relations Law of the United States $\$ 102$ (c) Comment d. See also, Norbett Horn, 'Normative Problems of a New International Economic Order', 16 J World Trade L. 343 (1982); Robert H. Jackson, Quasi-States: Sovereignty, International Relations and the Third World (1991) p. 202 (arguing that the NIEO was "unduly ambitious in that it attempted to replace free trade and cumulative justice with economic democracy and distributive justice").

46) Id.

47) Notably, in the interwar years, Soviet and Eastern European jurists of international law challenged international legal rules on foreign investor protection. These jurists argued that rules of international law could not regulate property relations within States. Within the socialist approach to economic governance, domestic law governed the rights of foreign investors and international adjudication of foreign investor rights was not permitted. Rules of international economic governance were also critiqued for being incompatible with a State-led model of economic governance. Thus, like Latin American jurists of the nineteenth century, these jurists contested the laissez faire underpinnings of the rules' international economic governance such as the inviolability of private property and the sanctity of contracts.

48) Guha-Roy, 'Is the Law of Responsibility of State for Injuries to Aliens a Part of Universal International Law', 55 Am. J. Int'l L. 863 (1961). See also S.K.B. Asante, 'Stability of Contractual Relations in the Transnational Investment Process', 28 Int'l and Comp. L.Q. 401 (1979); S. Sell, Power and Ideas: North South Politics of Intellectual Property and Antitrust (1998). 
Assembly and acting together as the Group of 77, developing countries also drafted and campaigned for the adoption of the Charter of Economic Rights and Duties of States (CERDS). The Charter reintroduced the Calvo doctrine's requirement of a uniform standard of treatment for domestic and foreign investors. ${ }^{49} \mathrm{It}$ also recognized the right of a State to nationalize foreign-owned property and the right of such a State to use its own law, as opposed to international law, to measure compensation after nationalization. The NIEO agenda sought to restructure international economic relations to establish a balance between the predominantly raw material producing economies of the capital-importing States and Western industrial economies. The NIEO challenged unfair international trading, investment and finance rules and advocated in favor of a right to development. ${ }^{50}$

The NIEO approach was informed by the theoretical work of dependency theorists who argued that countries that were formerly under colonial rule had failed to develop economically because of their peripheral position in the international economy. Under some of these dependency theories, capital-importing economies were thought vulnerable as a result of the poor terms of trade for their unprocessed raw materials and because of the downward trend in prices of their agricultural exports. Dependency theories attributed the shape of poorer economies on Western sources of aid, investment, and loans that favored industrial development at the expense of agriculture. Such policies, in turn, exploited the peasantry while enriching a comprador class. Rather than trace uneven development to internal problems within poor economies, dependency theorists emphasized the structural limitations of the global economy posed by huge multinational corporations, unequal exchanges between the north and the south, and the reliance on a few primary products for export among poor economies. ${ }^{51}$ Some scholars even proposed that poorer economies should unlink from the richer industrial economies to resolve the relational foundations of maldistribution of global wealth. ${ }^{52}$ The debate on the content, authority, and fairness of international investment rules particularly those relating to compensation for nationalization of alien property were captured in the following terms by the United States Supreme Court:

49) See B.H. Weston, 'The Charter of Economic Rights and Duries of States and the Deprivation of Foreign-Owned Wealth', 75 Am. J. Int'l L. 441 (1981).

30) Garcia-Mora, supra note 39, at 205-06.

51) F.H. Cardoso and E. Faletto, Dependency and Development in Latin America, (1978).

52) S. Amin, Accumulation on a World Scale: $A$ Critique of the Theory of Underdevelopment (Brian Pearce trans., 1974). See also Cardoso and Faletto, supra note 47. For a critique that the agenda of the NIEO replicated the old rules, strategies and institutions of liberal modernity it sought to overcome and therefore could not promise fundamental change, see Dianne Otto, 'Subalternity and International Law: The Problems of Global Community and the Incommensurability of Difference', 5 Soc. and Leg. Stud. 348 (1996). 
Certain representatives of the newly independent and underdeveloped countries have questioned whether the rules of state responsibility toward aliens can bind nations that have not consented to them and it is argued that the traditionally articulated standards governing expropriation of property reflect "imperialist" interests and are inappropriate to the circumstances of emergent states. The disagreement as to relevant international law standards reflects an even more basic divergence between the national interests of capital importing and capital exporting nations, between the social ideologies of those countries in favor of state control of a considerable portion of the means of production and those that adhere to a free enterprise system. It is difficult to imagine the courts of this country embarking on adjudication in an area which touches more sensitively the practical and ideological goals of the various members of the community of nations. ${ }^{53}$

While developing countries were challenging the fairness of rules of international economic governance in the 1960 s to the 1970 s as the foregoing observation suggests, some of them were also cautiously embracing these rules as well as marketbased models of national economic policy. For these countries, rules of international investment law including bilateral investment agreements provided a context within which they could enter into credible commitments with foreign investors. ${ }^{54}$ The adoption of market-based models of economic development resulted in the spectacular economic success of the East Asian economies such as South Korea. ${ }^{55}$ Whereas most of the East Asian economies were experimenting with market reforms from the 1960s, many other developing economies were far too skeptical. ${ }^{56}$

This rejection of market-led development on the part of some States was evident in the debates on the drafting of the Convention on the Settlement of Investment Disputes between States and Nationals of Other States in the late 1960s. ${ }^{57}$ Representatives of Asian States, such as Sri Lanka, feared that this new international investment tribunal would simply continue unequal economic relations between capital-importing and capital-exporting States. ${ }^{58}$ Scholars from thirdworld States have often noted how the rulings of the Tribunals of the Interna-

53) Banco Sabbatino de Cuba v. Sabbatino, 376 U.S. 398 (1964).

54) See Andrew T. Guzman, 'Why LDCs Sign Treaties That Hurt Them: Explaining the Popularity of Bilateral Investment Treaties', 38 Va. J. Int'l L. 639 (1998).

55) M. Sornarajah, 'ICSID Involvement in Asian Foreign Investment Disputes: The Amco and AAPL Cases', 4 Asian Y.B. Int' L. 69 (1994). For a view of the particular variation of free markets in the rise of the East Asian economies, relative to the neoliberal model known as the Washington Consensus, see Alice Amsden, 'Why Isn't the Whole World Experimenting with the East Asian Model to Develop?: Review of World Bank's East Asian Miracle Report', 22 World Dev. 4 (1994).

56) On this, see Deepak Lal, The Poverty of 'Development Economics,' pp. 24-36 (2000).

57) Sornarajah, ICSID Involvement, supra 49 note at 69-70. Clearly, developing countries had a love-hate relationship to international law; they loved its promise of autonomy but criticized its continuation of colonial inequalities. One of the best examples of this attitude is Bedjaoui, supra note 42. For a further discussion, see James Gathii, 'A Critical Appraisal of the International Legal Tradition of Taslim Olawale Elias', 21 Leiden J. Int'l L. 317 (2008) (arguing that a defining question for the first generation of scholars from the former colonies after World War II was "how to establish a doctrinal basis or a set of principles to address not only their frustration with international law, but also how its rules and institutions could contribute to the challenges of the newly independent states," $i d$. at 318-19).

s8) Id. at 70 n. 4. 
tional Center for the Settlement of Investment Disputes work against the interests of their States. ${ }^{59}$ This attitude is also reflected in the Libyan defense in arbitration proceedings that its decision to nationalize oil concessions in 1973 and 1974 was a nonarbitral sovereign act. In perhaps one of the most well-known arbitration investment decisions that followed, Arbitrator Rene-Jean Dupuy rejected Libya's decision. ${ }^{60} \mathrm{He}$ held that Libya's nationalization of the concessions it had granted alien investors could not be determined exclusively under Libyan law and in Libyan courts. In his view, the provision in the Charter of Economic Rights and Duties of States, which would have allowed for such an outcome, was adopted with 86 votes but more importantly 11 votes against and 28 abstentions. ${ }^{61}$ Among the objectors were capital-exporting States including the United States, Germany, Belgium, Spain, France, Japan, and the United Kingdom. Having found that the "most important [W] national law in determining compensation for nationalization, Arbitrator Dupuy then turned to the United Nations General Assembly Resolution on the Permanent Sovereignty over Natural Resources of $1962^{63}$ (PSNR). Dupuy noted that the PSNR, which was passed with the approval of "many States of the Third World, but also [by] several Western developed countries with market economies, including the most important one, the United States." ${ }^{\text {"D }}$ Dupuy concluded the appropriate compensation standard adopted in that resolution reflected the opinio juris communis because it reflected a "consensus by a majority of states belonging

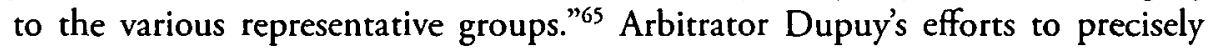
define the rules applicable to compensation for nationalization were also in issue in the Sabbatino decision of the U.S. Supreme Court about a decade earlier. Thus, in Sabbatino, the Court noted that its decision on a question related to the content of rules of compensation for takings would hardly be regarded as "disinterested expressions of sound legal principles by those adhering to widely different ideologies." 60 This self-consciousness about the controversies surrounding the

59) For example, M. Sornarajah, International Law on Foreign Investment (1994); Ibironke Odumosu, 'Locating Third World Resistance in the International Law on Foreign Investment', 9 Intl Community L. Rev. 427 (2007). For a view skeptical of these reservations, see Amazu A. Asouzu, International Commercial Arbitration and African States: Practice, Participation and Institutional Development (2001).

(6i) Texas Overseas Petroleum Co. v. Libyan Arab Republic, 17 I.L.M. 1 (1978). The outcome in this case contrasts sharply with that in the Sabbatino case discussed above, supra note 54 and accompanying text. (1) Id. at 985 .

62) Id. He also noted that a number of developing countries abstained on this question and attributed their abstention to their disagreement with disregarding international law on compensation for nationalizations.

63) G.A. Res. 1803 (XVII) U.N. Doc. A/RES/1803 (Dec.14 1962) (declaring in Article 4 that "[n]ationalization, expropriation or requisitioning shall be based on grounds of public utility, security or the national interest... [and] in such cases the owner shall be paid appropriate compensation").

64) Id. at 984.

65) Id. at 87.

66) Sabbatino, 376 U.S. at 429. For another decision indicating a limited rather than expansive view of the duty of compensation in international investment law, see Case Concerning Barcelona Traction, Light 
efficacy and authority of rules of international law in this period was also a reflection of the heated debates surrounding the large-scale nationalizations of natural resource concessions and entire industries that characterized the period following decolonization. ${ }^{67}$ The debate continues to date on the appropriate standard for compensation for expropriation. ${ }^{68}$

Although international law is now widely accepted as governing international investment and commercial disputes, the uncertainty about the precise content of many of its governing rules and the growing propensity particularly in bilateral investment treaties ${ }^{69}$ (BITs) to overprotect the rights of investors has led a leading first-world scholar to refer to BITs, which often provide the applicable rules for International Centre for Settlement of Investment Disputes (ICSID) tribunals, as "bills of rights for foreign investors." ${ }^{70}$ In the recent past, Bolivia denounced the

and Power Co. (Belg. v. Swed.) 1970 I.C.J. 4 (Feb. 5) (holding that shareholder interests are indirect interests that do not qualify for international legal protection, and a claimant State cannot espouse the claim of its nationals who have invested in foreign corporations absent treaties or agreements providing for such protections).

67) For perhaps this reason in Sabbatino, supra note 54, Justice Harlan in similar circumstances as those in the Libyan case declined to invoke international law as Arbitrator Dupuy. Justice Harlan instead held that, "[w]e decide only that the Judicial branch will not examine the validity of a taking of property ... in the absence of a treaty or other unambiguous agreement regarding controlling legal principles, even if the complaint alleges that the taking violates customary international law." Sabbatino, 376 U.S. at 428; see also Richard Falk, The Status of Law in International Society (1970) pp. 409-13; Richard Lillich, The Protection of Foreign Investments (1978) pp. 77-78; Jordan Paust, 'Correspondence', 18 Va. J. Int'l L, 601-03 (1978).

68) The "prompt, adequate and effective compensation" formulation of the Hull diplomatic note has been rejected by many capital-importing States. For example, Mexico rejected it in 1938. See 1938 Correspondence between United States and Mexico, excerpted in 5 G. Hackworth, Dig. Int'l L. 655-65 (1942); see also Oscar Schachter, 'Compensation for Expropriation', 23 Colum. J. Transnatl L. 615, 616 (1985) (arguing that there is a dispute as to whether the Hull formula represents customary international law). In addition, three UN resolutions have embraced the view that national treatment rather than prompt adequate and effective compensation is the rule governing expropriations. See G.A. Res. 3171, U.N. GAOR, 28th Sess., Resolution on the Permanent Sovereignty over Natural Resources, G.A. Doc. 3171/XXVII (1973); G.A. Res. 3201, Declaration on the Establishment of a New International Economic Order, 29th Sess., G.A. Doc. 3201/VI-6 (1974); G.A. Res. Charter of Economic Rights and Duties of States, 30th Sess., G.A. Doc. 3281/XXIX (1975). On the uncertainty of customary international law relating to foreign investment particularly in relation to bilateral investment treaties (BITs), see Bernard Kishoiyan, 'The Utility of Bilateral Investment Treaties in the Formulation of Customary International Law', $14 \mathrm{Nw}$. J. Int' L. and Bus. 327 (1994) (exploring the various compensation standards in a variety of BITs and concluding there is no universally agreed standard because the practice evidences "so much uncertainty and contradiction" as well as "so much fuctuation and discrepancy," id. at 372). For an overview of various standards applied in a variety of contexts, see R. Doak Bishop, James Crawford and W. Michael Reisman, Foreign Investment Disputes: Cases, Materials and Commentary 1298-325 (2005).

69) Other notable examples here include the North American Free Trade Agreement (NAFTA), which includes an investment chapter that effectively guarantees investors compensation for losses arising from a regulatory measure that a NAFTA member may take to protect the environment. On this, see Frederick M. Abbot, 'The Political Economy of NAFTA Chapter Eleven: Equality Before the Law and the Boundaries of North American Legal Integration', 23 Hastings Int'l and Comp. L. Rev. 303 (2000).

70) Jose Alvarez, 'North American Free Trade Agreement's Chapter Eleven', 28 U. Miami Inter-Am. L. Rev. 303, 308 (1996-97) (also arguing that NAFTA is a "bilateral investment treaty on steroids," id. at 304). This theme is further echoed in Philippe Sands, Lawless World: America and the Making and Break- 
ICSID Convention and withdrew from it, arguing multinational corporations used ICSID Tribunals to resist the exercise of sovereign responsibilities such as environmental laws. There are also several other Latin American countries including Bolivia, Venezuela, and Nicaragua that announced their opposition to and intention to denounce the ICSID Convention. ${ }^{71}$ For precisely this reason, the United States Congress in 2002 enacted the No Greater Rights Than principle, under which foreign investors have no greater rights than a U.S. citizen under the U.S. Constitution and local laws. In effect, whereas a U.S. corporation abroad has the full protections of an investor to challenge foreign laws and regulatory regimes standing in the way of their investment opportunities, foreign investors in the United States enjoy no such rights. ${ }^{72}$

Ultimately, arbitration proceedings before bodies such as the ICSID are an indication of how international investment law has empowered private actors, such as multinational corporations, to bring suit against States hosting their investments. By giving private actors the power to sue and have a choice with regard not only as to forum but as of the applicable law as well, vests these actors with enormous legal authority over host States over which they may already exercise significant market leverage. In short, although the significance of the diplomatic protection of foreign investment through forcible means has largely declined, the role of privatized investment dispute forums that have no oversight

ing of Global Rules from FDR's Atlantic Charter to George W. Bush's Illegal War (2005) pp. $117-42$ (noting the tendency to interpret international investment rules in isolation of other international law rules and to give priority to investor rights over rules that protect human rights and the environment). See also Upendra Baxi, The Future of International Human Rights (1999) p. 235 (noting the ascendance of a traderelated, market-friendly approach to human rights under the aegis of globalization).

71) For an analysis, see Igacio Vincentelli, The Uncertain Future of ICSID in Latin America, available at http://ssrn.com/abstract=1340816. On Bolivia's denunciation, see International Centre for Settlement of Investment Disputes (ICSID), List of Contracting States and Other Signatories to the Convention (as of Nov. 4, 2007), available at http://icsid.worldbank.org/ICSID/FrontServlet?request Type=ICSIDDocRHa ndactionVal=ContractingStatesandReqFrom=Main (last visited Jan. 25, 2009). In addition, note that Venezuela in 2008 denounced its BIT with the Netherlands. In addition, the Venezulean Supreme Court has decided that any decision of an ICSID Tribunal inconsistent with Venezuelan law would be unenforceable in Venezeula, see Vincentelli, supra note 71.

72) The immediate reason relating to U.S. concern about Chapter 11 of NAFTA arose from a suit filed against the United States by Methanex, a Canadian company claiming $\$ 970$ million compensation for business it would lose because of California's plan to phase out the use of methyl tertiary butyl ether (MTBE), an oxygenate that cleans gasoline, because of concerns the additive was contaminating drinking water supplies. Methanex argued that the ban was not based on scientific evidence, and the water pollution could be solved by fixing leaking underground storage tanks at gas stations. California was the largest market for Methanex and was important because it sets environmental standards that are adopted by other states. Methanex alleged in the suit that the ban was necessitated by political considerations including the financial contributions to the campaign of Governor Gray Davis of California by Archer Daniel Midlands Corporation, which produces a competing oxygenate from corn. In August 2002, a binational panel decided not to proceed with the case since there was inadequate evidence to make a determination. See Allen Dowd, NAFTA Panel Says Cannot Rule on Methanex MTBE Case Reuters (Aug. 7, 2002) available at http://www.mindfully.org/WTO/Methanex-MTBE7aug02.htm. 
has grown. ${ }^{73}$ This, together with the retaliatory threats exercised by capital-exporting States to protect their investors and interests in capital-importing States, in many ways tilts international economic governance in favor of investors from capital exporting States. ${ }^{74}$ To continue this exploration of the power of international investment law over capital-importing States, Section V examines a decision of the ICSID in the context of State responsibility for war destruction.

\section{State Responsibility for War Destruction in Investment Disputes}

\section{Asian Agricultural Products Limited (AAPL) v. Democratic Socialist Republic of Sri} Lanka was an ICSID case that raised the question of State responsibility for war destruction. ${ }^{75}$ AAPL, a foreign-owned firm operated a prawn farm under the name, Serendib Seafoods Limited, a Sri Lankan public company in which the Sri Lankan government participated in as an equity partner. AAPL claimed damages for losses it suffered on the Prawn farm as a result of a military operation conducted by the Sri Lankan military against Tamil tiger fighters.

Besides claiming liability on a war destruction clause, AAPL primarily based its claim on the view that Sri Lanka bore "strict or absolute liability" under a BIT Sri Lanka had signed with Great Britain and Northern Ireland. ${ }^{76}$ AAPL argued that

\footnotetext{
73) For an excellent view, see Ibironke T. Odumosu, 'Locating Third World Resistance in the International Law on Foreign Investment', 9 Int'l Community L. Rev. 427 (2007). See also Ibironke T. Odumosu, 'The Antinomies of the (Continued) Relevance of the ICSID to the Third World', 8 San Diego J. Intl L. 345 (2007).

74) One of the best-known retaliatory threats is Super 301 contained in the Trade Act of 1974, 19 U.S.C. $\$ 2242$ (2000), amended by Omnibus Trade and Competitiveness Act of 1988, Pub. L. No. 100-416, 102 Stat. 1105. Under this section, the United States Trade Representative (USTR) is required within thirty days after the submission of the annual National Trade Estimates (foreign trade barriers) to report to Congress those foreign countries that (1) "deny adequate and effective protection of U.S. intellectual property rights" and (2) those countries under (1) "that are determined by the USTR to be priority foreign countries." Id. The USTR identifies as priorities only those countries "that have the most onerous or egregious acts, policies, or practices that ... have the greatest adverse impact on the relevant United States products and that are not entering into good faith negotiations or making significant progress in bilateral or multilateral negotiations to provide adequate and effective intellectual property rights" protection. Id. The United States blacklisted India and Brazil leading up to the conclusion of the Uruguay Round of negotiations thereby effectively ending their opposition to the Uruguay Round bargain. See James Gathii, 'Construing Intellectual Property Rights and Competition Policy Consistently with Facilitating Access to Affordable Aids Drugs to Low-End Consumers', 53 Fla. L. Rev. 756 (2001). In a challenge at the World Trade Organization (WTO), this provision of U.S. law was sustained. See World Trade Organization Report of the Panel, United States-Sections 301-310 of the Trade Act of 1974, WT/DS152/R 97.22 (Dec. 22, 1999).

75) Asian Agric. Prod. Ltd. v. Democratic Socialist Republic of Sri Lanka, ICSID Case No. ARB/87/3, available at http:// www.worldbank.org/icsid (follow "cases" hyperlink; then follow "List of Cases" hyperlink; then follow "Concluded Cases" hyperlink; then scroll to "Asian Agricultural Products Limited v. Democratic Social ist Republic of Sri Lanka (ICSID Case No. ARB/87/3)") [hereinafter AAPL v. Sri Lanka].

76) Id. at 9 9. The Tribunal's majority opinion found that in light of the failure of the parties to agree on a choice of law, during the arbitration proceedings, they had presented their case in a manner that showed that they mutually agreed that the provisions Sri Lanka-UK BIT was "the primary source of the appli-
} 
the customary international law due diligence standard of State responsibility had been replaced by this new rule of "strict or absolute liability." AAPL claimed that the "most favored nation" and "full protection and security" 77 clauses in the treaty imposed "strict or absolute liability" even if it could be shown that AAPL's investments were destroyed by persons whose conduct could not be attributable to Sri Lanka and under circumstances beyond its control. In fact, as the Tribunal noted, AAPL exhibited "hostility to the general applicability of customary international law rules" and showed "reluctance to admit Sri Lankan domestic law as the basic governing law." ${ }^{78}$ Suffice it to say here, AAPL's claims are consistent with the traditional attitude investors have of overstating the responsibility of host States beyond that recognized under customary international law. As Sri Lanka argued in response, with the concurrence of the Tribunal, the "full protection and security" clause of the treaty could not be construed to impose strict or absolute liability. ${ }^{79}$ In fact, the Tribunal noted it could find no case in which such a clause had been construed to impose a strict or absolute liability on a host State. ${ }^{80}$ This conclusion was also endorsed in the dissenting opinion of one of the arbitrators. ${ }^{81}$

Having rejected AAPL's novel but not unusual basis for seeking to hold Sri Lanka liable, the Tribunal then moved to consider Sri Lanka's liability under the war destruction clause of the treary. Under this clause, the Contracting Parties were liable for losses suffered "owing to war or other armed conflict, revolution, a state of national emergency, revolt, insurrection or riot in the territory." 82 Sri Lanka argued that, for it to be held liable under this clause for failing to act reasonably under the circumstances, it had to be shown that it had been "negligent in the use of or in the failure to use, the forces at its disposal for the prevention or suppression of the insurrection." 83

According to the Tribunal, the duty of vigilance required to establish the "degree of security reasonably expected" depended on the circumstances. ${ }^{84}$ The Tribunal noted this degree of security could be established by Sri Lanka's failure

cable legal rules," id. at $\mathbf{9} 20$. However, the dissenting opinion of one member of the Tribunal, S.K.B. Asante took issue with the tribunal's finding that the treaty was the primary source of rules for determining the dispute, see dissenting opinion of S.K.B. Asante in ICSID Rev.-Foreign Inv. L.J. 576-78 (1990).

m) AAPL v. Sri Lanka, supra note 75, at 926 (A), where AAPL argues argued that "the ordinary meaning of the words 'full protection and security' points to an acceptance of the host state of strict or absolute liability." Further AAPL argued that under the treaty, the "full protection and security clause" had to be read as "autonomous in character and independent of any link to customary international law." Id. at T 26(B).

78) Id. at $\mathbf{9} 23$.

79) $I d$ at 932 .

80) Id. $9948-55$.

81) Id. at 94 (Asante, S.K.B., dissenting).

82) AAPL u. Sri Lanka, supra note 75 at $\mathbf{9} 65$. Under the treaty, liability would be remediable by "restitution, indemnification, compensation or other settlement," id. at $\mathbf{9} 66$.

83) Id. at $\mathbf{9} 69$.

84) Id. at 973. 
to take by "all means reasonably necessary" steps to prevent acts of revolutionaries that caused injury or damage to AAPL's investment. ${ }^{85}$

AAPL argued that the destruction of its "office structure, repair shed, store and dormitory," as well as "the opening of its sluice gates to the grow-out ponds," and the resulting destruction of its prawn crop and the death of 21 of its staff members, was not necessary because "less destructive" measures short of the destruction and murders could have been taken by the Sri Lankan military. ${ }^{86}$ Sri Lanka countered by arguing that its operation on AAPL's farm was necessary to "prevent the spread of terrorism and the erosion of government control in the towns surrounding the shrimp farm." ${ }^{87}$ The government also contended the farm had been used by the Tamil rebels as an operations base; that the farm's management had cooperated with the rebels' and that the Tamil fighters had engaged in fierce combat with the Sri Lankan Special Task Force on the day of the raid. Sri Lanka argued that it was the Tamil fighters who had actually occasioned the damage complained of by AAPL. ${ }^{88}$ It was agreed by both Sri Lanka and AAPL that the area in which the farm on which the damage occurred was infiltrated by Tamil fighters and was out of the control of the Sri Lankan government for several months before the raid. ${ }^{89}$

The Tribunal found the Sri Lanka government had not acted reasonably because it had failed to use peaceful alternatives in dealing with Tamil fighters, an option in the Tribunal's opinion the government had because it had established a "high level channel of communication in order to get any suspect elements excluded from the farm." ${ }^{90}$ According to the Tribunal, Sri Lanka's:

[F]ailure to resort to such precautionary measures acquires more significance when taking into consideration that such measures fall within the normal exercise of governmental inherent powers - as a public authority - entitled to order undesirable persons out from security sensitive areas. The failure became particularly serious when the highest executive officer of the Company [AAPL] reconfirmed just ten days before his willingness to comply with any governmental requests in this respect. ${ }^{91}$

Having no evidence of either Sri Lankan forces being directly responsible for the damage or even having had control of AAPL's premises or that the Tamil fighters caused the damage, the Tribunal nevertheless found Sri Lanka liable. In the Tribunal's view, the appropriate course of conduct was either to "institute judicial

\footnotetext{
85) Id. at $\mathbf{9} 73$.

86) Id. at 979.

87) Id. at $\mathbf{9} 82(\mathrm{a})$.

88) Id. at 9 82(b)-(e).

89) Id. at $985(\mathrm{a})$.

90) Id at 9 85(b).

91) Id.
} 
investigations against them to prove their culpability or innocence, or to get them off the Company's farm." 92

According to the Tribunal, Sri Lanka had failed to give full protection and security to AAPL's farm and it was therefore liable. ${ }^{93}$ As such, Sri Lanka's decision to deal with, what was essentially a national security issue forcibly, particularly because it involved claims relating to terrorism was reviewable in international investment proceedings if it conflicted with its treaty obligations to protect AAPL's commercial rights.

The dissenting opinion in the case regretted that the Tribunal's decision failed "to appreciate the full implications of the formidable security situation and the grave national emergency that confronted the Sri Lankan authorities." ${ }^{4}$ It went on to note that it was not in dispute that the entire province within which the investment losses had occurred had been embroiled in civil war pitting the government against "a powerful and well-armed group" that were engaged in "sophisticated guerilla warfare against the Sri Lanka government forces," which had established its headquarters within 1.5 miles of the farm where the losses occurred. ${ }^{96}$ As a result, even the managing director of AAPL had not been able to visit the farm for six months prior to the government's counter-insurgency operation during which the investment losses occurred. ${ }^{77}$

Article 4 of the Sri Lankan-Great Britain BIT provided for circumstances under which liability for compensation arises when investment losses result from war or other armed conflict, revolution, state of emergency, revolt or insurgency, and where the losses resulting are attributable to the host State or its agents. ${ }^{98}$

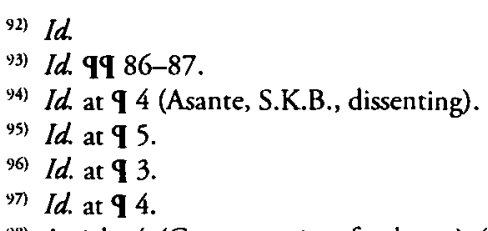

98) Article 4 (Compensation for losses) (1) Nationals or companies of one Contracting Party whose investments in the territory of other Contracting Party suffer losses owing to war or other armed conflict, revolution, a state of national emergency, revolt, insurrection or riot in the territory of the latter Contracting Party shall be accorded by the latter Contracting Party treatment, as regards to restitution, indemnification, compensation or other settlement, no less favorable than that which the latter Contracting Party accords to its own nationals or companies of any third State; (2) Without prejudice to paragraph (1) of this Article, nationals and companies of one Contracting Party who in any of the situations referred to in that paragraph suffer losses in the territory of the other Contracting Party resulting from (a) requisitioning of their property by its forces or authorities, or (b) destruction of their property by its forces or authorities which was not caused in combat action or was not required by the necessity of the situation, shall be accorded restitution or adequate compensation. Resulting payments shall be freely transferable.

Asante's dissenting opinion proceeded on the view that because Article 4 was more specific to issue in dispute than the full protection and most-favored nation clauses, it applied to the situation. Noted Asante, "Article 4(2) is crucial, first, because as the lex specialis berween Sri Lanka and the U.K. spelling out specific grounds of liability in the particular situations defined in Article 4(1), it must prevail as the definitive source of liability in respect of the conduct of the armed forces of the host State." Supra note 57, at 585 (Asante, S.K.B., dissenting). 
Under this Article, State responsibility is precluded where investment losses are not attributable to a State or where the destruction is "not caused in combat action or by the necessity of the situation." ${ }^{99}$ Quoting extensively from the literature on responsibility for war destruction, the dissenting opinion arrived at two conclusions. First, that the provisions of Article 4 of the treaty were a statement of the customary international law position on responsibility for war destruction. Second, that responsibility for war destruction did not prescribe a substantive obligation on the part of the host State to pay compensation where foreign investments sustain losses by reason of war or other armed conflict, revolution, a state of national emergency, revolt or other civil disturbance." ${ }^{100}$ In other words, the treaty provision only contained the customary international law provision of property and/or investment protection, contrary to the Tribunal's interpretation as a specific undertaking on the part of Sri Lanka "to pay compensation to all aliens from all countries." 101

The dissenting opinion noted that, even if the treaty clause could be interpreted as the Tribunal had done, Sri Lanka had effectively waived this obligation in its Constitution in so far as the obligation conflicted with its national security. ${ }^{102}$ Thus, although the Tribunal's opinion focused primarily on the exceptional circumstances under which a State is responsible for war destruction relating to wanton destruction or unnecessary force, the dissenting opinion focused on the general rule of customary international law under which a State is not responsible for investment losses arising from war, armed conflict, insurrection, revolt, riot, a national emergency, or other civil disturbances where the destruction was caused in combat or by the necessity of the situation.

Applying this rule of customary international law, the dissenting opinion proceeded as follows. First, it was not in contention there was a general insurrection in the area where AAPL had its shrimp factory and that the government had been engaged in seeking to regain control of the area. Further, that this was "a legitimate and praiseworthy act of a sovereign government." ${ }^{103}$ Second, both Sri Lanka and AAPL, as the Tribunal found, had insufficient evidence to definitively establish who destroyed AAPL's farm. As such, the dissenting opinion found that AAPL had "failed to establish the fundamental basis of the claim, namely that the

\footnotetext{
99) AAPL v. Sri Lanka, supra note 75, at Art. 4(2).

106) Dissenting opinion of Asante, supra note 57, at 585-86.

101) Id. at 588. Asante notes that such an interpretation of Article 4(1) of the Treaty was more consistent with the understanding of the most favored nation (MFN) provision and as such, the majority opinion had in effect obliterated "the juridical distinction between the concept of most favored nation treatment, a creature of treaty, and the general requirements of customary international law," id. at 589.

102) Id. at 589. It is not unusual for commercial or trade treaties to have security exceptions. Article 21 of the General Agreement on Tariffs and Trade, 1948 as amended in 1994 embodies such an exception.

103) Id. at 592.
} 
Government's security forces had used excessive force in its military operation resulting in the wanton destruction of the farm." 104

The dissenting opinion then proceeded to argue why it found the Tribunal's argument that Sri Lanka was liable for failing to use precautionary measures unconvincing. The dissent noted that the Tribunal raised the "fundamental question" regarding the propriety of the decision to engage in a military operation at that particular time, a question which "touches on the sovereign prerogatives of a Government fighting for its very life." 105 The dissent noted it would not have been feasible for the Sri Lankan government to be expected to have taken the sort of precautionary measures that the Tribunal held it should have, as it was engaged in sophisticated guerilla war fare against powerful insurgents. ${ }^{106}$ Ultimately, the dissent noted that "the applicable rules and principles of customary international law, the regime of property protection under the Sri Lanka/Great Britain Treaty and Article 157 of the Sri Lankan Constitution all recognized that the requirements of national security warrant a departure from the normal principles of responsibility in respect of the protection of foreign property."107

Although the vigorous debate between the dissent and the opinion of the ICSID Tribunal in APL v. Sri-Lanka may be exceptional, ${ }^{108}$ holding capital importing States responsible for war destruction is not unusual. In a later arbitration, American Manufacturing \& Trading, Inc. v. Republic of Zaire, ${ }^{109}$ the arbitrators found that the then Zaire had failed to fulfill its obligation of vigilance to prevent the occurrence of acts of violence on its territory that had resulted in the looting and destruction of investments made by American Manufacturing and Trading Inc. In this case, unlike in AAPL v. Sri Lanka, Zaire did not contest its responsibility for destroying and looting the investor's property, finished goods, raw materials, and other objects of value. However, consistent with the dissent in $A A P L v$. Sri Lanka, Zaire argued that, because it had not compensated domestic businesses and other foreign investors, Article IV of its BIT with the United States was unavailable. The arbitration panel, however, found that the clause did not require such national treatment. The finding against Zaire was arguably much

104) Id.

105) Id. at 593.

106) Id. at 594 .

107) Id. at 594-95.

10*) For critical commentary on the AAPL v. Sri Lankan case, see Stephen C. Vascianne, 'Bilateral Investment Treaties and Civil Strife: The AAPL/Sri Lanka Arbitration', 39 Neth. Intl L. Rev. 332 (1992) (noting respects in which the decision of the Tribunal would reduce its utility as a precedent in future cases) and A. Rohan Perera and Noel Dias, 'Asian Agricultural Products Ltd v. The Republic of Sri Lanka', 2 Am. Rev. Int'l Arb. 217 (1991) (discussing the Tribunal's misinterpretation of Article 4(1)).

(*)) ICSID Case No. ARB/93/1. Award of Feb. 21, 1997, 36 1.L.M. 1531 (1992), available at http:// www.worldbank.org/icsid (follow "cases" hyperlink; then follow "List of Cases" hyperlink; then follow "Concluded Cases" hyperlink; then scroll to "American Manufacturing and Trading, Inc. v. Democratic Republic of the Congo (ICSID Case No. ARB/93/1)" [hereinafter Am. Mfg. and Trading, Inc. v. Republic of Zaire]. 
broader than in AAPL v. Sri Lanka. This is particularly so given that the primary basis for holding Zaire responsible was the full protection and security clause that the AAPL v. Sri Lanka Tribunal had avoided as a basis of holding Sri Lanka responsible. In addition, unlike in $A A P L \nu$. Sri Lanka, damage to the investors' property was not caused by its armed forces or army, but rather by rioters and looters. ${ }^{110}$ Ultimately, unlike in $A A P L \nu$. Sri Lanka, the Tribunal found against Zaire primarily under the full protection and security clause of its BIT with the United States 111 and only secondarily under Article IV, the war destruction clause on which the AAPL v. Sri Lankan Tribunal had relied on to hold Sri Lanka responsible.

Finally, in Wena Hotels Limited v. Arab Republic of Egypt, the ICSID Tribunal, without much discussion, found that Egypt had violated the full protection and security clause of UK-Egypt Agreement for the Promotion and Protection of Investments in the forcible seizure of a hotel. ${ }^{112}$ The Tribunal cited the American Manufactures $v$. Zaire case for the proposition that States have an obligation of vigilance "to ensure the full enjoyment of protection and security" of their investments and that a country could not "invoke its own legislation to detract from any such obligation." 113 Thus, the controversial origins of responsibility for war destruction in $A A P L v$. Sri Lanka have evolved in an ever-tightening obligation on States to take preventive measures to avoid loss or damage to the property of alien investors in the context of war and domestic unrest. ${ }^{114}$ Therefore, although ICSID Tribunals cite $A A P L \nu$. Sri Lanka for the proposition that full security and protection do not embody absolute obligations, ${ }^{115}$ the effect of these decisions has been to effectively heighten the obligations of States for war destruction toward such absoluteness and strictness.

This heightened standard of State responsibility for war destruction is clearly demonstrated when one compares the standard of vigilance States have in the investor context, with that in the context of ensuring their territory is not used for

110) Id. at $97.01,7.09$.

11i) The Tribunal found that Zaire had "manifestly failed" to comply with its duty of vigilance and care by its failure to take precautionary measures to protect the investors property, $i d$. at 99 6.04-6.11. The Tribunal found that the protection and security obligation in Article II of the BIT was reinforced by "a special Article IV on compensation for damages due to war, or similar events, including riots and acts of violence." Id. at 99 6.12-6.14.

112) Wena Hotels Led. v. Arab Republic of Egypt, ICSID Case No. ARB/98/4; 41 I.L.M. 896 (2002).

113) Id. at $\mathbf{9} 84$.

114) See also CME Czech Republic B.V. (The Netherlands) v. The Czech Republic, Partial Award, Sept. 13, 2001 and Azurix Corp. v. Argentina, ICSID Case No. ARB/01/12, Award, July 14, 2006, which show how ICSID Tribunals have heightened the responsibility of States under the full protection and security clauses of BITs to go beyond the kind of security that may be provided by security forces and in particular to include a secure investment environment - arguably much superior to that enjoyed by domestic investors. For another example, see Occidental Exploration and Prod. Co. v. The Republic of Ecuador, Award, July 1, 2004 at 9187 , where Ecuador's amendment of its tax laws was found to constitute a violation of its obligation to provide full protection and security to investors.

115) E.g., supra note 112 , at 984. 
purposes inimical to other States. In Democratic Republic of Congo v. Uganda, the International Court of Justice (ICJ) strongly suggested that the duty of due diligence or vigilance expected of a government with respect to rebel activity that may result in violating the rights of a neighboring State may be lower if the geographical terrain was remote and difficult. ${ }^{116} \mathrm{In}$ fact, this is the customary international legal standard of due diligence that imposes a reasonable, rather than an absolute, standard of conduct. Under such a standard, a State is assumed to have the means to provide protection. As such if its ability to provide protection was remote, liability would not automatically attach. ${ }^{117}$ In addition, this standard is based on the assumption that a State had the opportunity to "prevent the act but failed to do so." 18 Taken together, these tests require before imposition of liability that the conduct of the [S] tate be "judged by [its] reasonableness under the circumstances." 119 This, in my view, is the approach taken by the ICJ in Congo $v$. Uganda. Clearly, the heightening of the responsibility of States for war destruction is consistent with the heightening of the responsibility of States in the terrorism context. Yet, the obligations of investors have remained the same.

To be sure, there are arbitration decisions that have found essential security interests escape clauses in BITs between capital-importing and capital-exporting States can operate to preclude capital-importing States from being held responsible. Thus in LG\&E Energy Corp. v. Argentine Republic, ${ }^{120}$ the Tribunal found that Argentina's decision to convert tariff denomination from U.S. dollars to Argentinian pesos as a part of its economic recovery plan did not constitute a violation of its treaty obligations to the foreign investor. The Tribunal rejected the claimants contention that essential security interests had to be necessarily of a

116) Case Concerning Armed Activities on the Territory of the Congo (Dem. Rep. Congo v. Uganda), 2005 1.C.J. 116 at 9304 (Dec. 19).

117) Richard Lillich and Paxman, 'State Responsibility for Injuries to Aliens Occasioned by Terrorist Activities', 26 Am. Univ. L. Rev. 217 (1977).

18) Id. This view is also confirmed by the International Law Commission's Draft Articles on Prevention of Transboundary Harm from Hazardous Activities, which discusses the duty of due diligence and specifically explains that the degree of due diligence expected of a State differs from a State that has a "welldeveloped economy and human and material resources and with highly evolved systems and structures of governance is different from States which are not so well placed. Even in the latter case, vigilance, employment of infrastructure and monitoring of hazardous activities in the territory of the State, which is a natural attribute of any Government, are expected," International Law Commission, Draft Articles on Prevention of Transboundary Harm from Hazardous Activities, at 395, available at http://untreaty.un.org/ilc/texts/ instruments/english/commentaries/9_7_2001.pdf (last visited Aug. 16, 2006).

119) Lillich and Paxman, supra note 117.

120) LGandE Energy Corp. v. Argentine Republic, ICSID Case. No. ARB/02/1 (Decision on Liability), Oct. 3, 2006. Other victories outside the context of the war destruction clause in BITs include Patrick Mitchell v. Democratic Republic of Congo, ICSID Case No. ARB/99/7 (Decision on the Application for Annulment of the Award, Nov. 1,2006 ) where an award was annulled on the grounds that the investment that had been the subject matter of the claim did not fall within the definition of an investment in a United States-Zaire BIT. 
military nature or involving war to preclude State responsibility in the context of a severe economic crisis. ${ }^{121}$

Such cases show that it is possible to imagine a different liability regime for war destruction in BITs. There are a few BITs between developed and developing countries that have an escape clause to safeguard security interests of the signatory countries in the same way that Article 21 of the General Agreement on Tariff and Trade (GATT) does. ${ }^{122}$ This clause, already contained in some U.S. BITs provides " $[t]$ his Treaty shall not preclude the application by either Party of measures necessary for the maintenance of public order, the fulfillment of its obligations with respect to the maintenance and restoration of international peace or security, or the protection of its essential security interests." 123

Such an escape clause would work perhaps the same way the national security exception in GATT does. The GATT security escape clause allows member States to invoke national security as an excuse to depart from the rules of nondiscriminatory trade without risking the imposition of compensating trade concessions for departing from these otherwise binding obligations. ${ }^{124}$

\footnotetext{
121) Supra note 120, at 9238 . In this case Argentina prevailed in showing that it faced a severe economic crisis that threatened its economic and political survival that precluded it on the basis of a state of necessity from being responsible for measure taken (these included freeing gas distribution tariffs and abandoning calculation of tariffs in dollars) to address the crisis that also occasioned losses to LGandE Energy Corporation investments in Argentina, id. at 99236 and 266. See also In re CMS Transmission Co. and the Argentine Republic, Case No. ARB/01/08 (Award of May 12, 2005) (where the tribunal concluded that a State is free to adopt emergency measures "it consider appropriate without requesting the views of any court" pursuant to a provision of a BIT authorizing a State to adopt measures in response to threats to its security interests, id. at $\mathbf{9}$ 373). For further analysis, see William W. Burke-White, 'The Argentine Financial Crisis: State Liability Under BITs and the Legitimacy of the ICSID System', 3 Asian J. WTO and Int'l L. and Policy 199 (2008) (this article analyzes four ICSID Tribunal rulings arising from Argentina's response to its financial crisis in 2001-2002. The author argues this jurisprudence is deeply problematic because the four tribunals gave different interpretations of Argentina's response, whereas in fact Argentina made the same arguments in all four cases). Inconsistent arbitration rulings in similar cases is not all that unusual, see Susan D. Franck, "The Legitimacy Crisis in Investment Treaty Arbitration: Privatizing Public International Law through Inconsistent Decisions', 73 Fordham L. Rev. 1521 (2005). See also Andrea K. Bjorklund, 'Reconciling State Sovereignty and Investor Protection in Denial of Justice Claims', 45 Va. J. Int'l L., 809 (2005) (arguing that denial of justice standard is malleable and may therefore not result in a well-reasoned body of jurisprudence).

122) Anne van Asken, 'Perils of Success? The Case of International Investment Protection', 9 Eur. Bus. Org. L. Rev. 1-27, (March 2008), available at http://papers.ssrn.com/sol3/papers.cfm?abstract_id=1020959 Even better would be having international investment decisions made in a manner that takes into account the circumstances in a country in the same way social and economic rights under international law are conditioned on availability of resources or on the principle of progressive realization. For further analysis, see Emily A. Alexander, 'Taking Account of Reality: Adopting Contextual Standards for Developing Countries in International Investment Law', 48 Va. J. Int'l L., 817 (2008)

123) See Anne van Asken, supra nore 122 at page 13.

124) Art. XXI(b)(iii) of GATT provides that: "Nothing in this Agreement shall be construed ... to prevent any contracting party from taking... in time of war or other national emergency in international relations... any action which it considers necessary for the protection of its national security interests." Remarkably, this security exception in the GATT regime is very similar in substance to the doctrine of
} 
For example, in 1985, the United States prohibited the importation of all goods and services of Nicaraguan origin as well as exports from the Unired States into Nicaragua. ${ }^{125}$ Nicaragua lodged a complaint before a GATT panel arguing in part that this prohibition had nullified and impaired trade benefits it had accrued inconsistently with U.S. GATT obligations. ${ }^{126}$ Nicaragua further argued that the United States and Nicaragua were not at war, and that they had maintained diplomatic relations. Instead, Nicaragua argued that as "a small developing country," it had not attacked the United States and could not pose a security threat to the United States. Nicaragua argued that it was the United States that was using force against Nicaragua inconsistently with the prohibition against the use of force. ${ }^{127}$ Nicaragua referred the GATT panel to a decision of the International Court of Justice, finding that the United States had violated the nonuse of force prohibition of the UN Charter. For Nicaragua, the GATT had to be interpreted in accordance with rather than inconsistently with international law. ${ }^{128}$

The United States, by contrast, argued that the panel could examine neither the validity nor motivation for the invocation of national security as an excuse for departing from its GATT obligations. In short, the U.S. case was simply that a GATT member country could, in its sole discretion, determine when its national security was threatened and as such, could decide to depart from its GATT obligations. In cases involving national security, the United States argued that the nullification or impairment of benefits under the GATT agreement could not be presumed. ${ }^{129}$ In the U.S. view, the dispute was political and the judgment of the International Court of Justice was not only irrelevant to the dispute, ${ }^{130}$ "but clearly outside the Panel's terms of reference."131

Agreeing with the United States, the GATT panel determined that it was precluded from examining the justification and as such the validity and motivation for the U.S. invocation of GATT's national security exception. ${ }^{132}$ This issue of whether a security escape clause in a bilateral investment treaty can be invoked

suspension that allowed belligerents to confiscate private property in war but to return it on cessation of hostilities.

125) Exec. Order No. 12,513, 3 C.F.R. 342 (1985). The only exception to this ban was goods intended for the democratic resistance. The order also banned air and naval transportation to and from Nicaragua to the United States. This ban was issued under the expansive authority the U.S. President enjoys under the International Emergency Economic Powers Act (IEEPA), see Dames and Moore, 453 U.S. at 699 noting that the language of the IEEPA is "sweeping and unqualified," id.

126) Report of the Panel, United States - Trade Measures Affecting Nicaragua (L/6053) (Oct. 13, 1986).

127) Id. at 94.5 .

128) Id. Further, Nicaragua's argument in this case that "GATT did not exist in a vacuum but was an integral structure of international law" foreshadowed the Treaty Establishing the WTO of 1994, which affirmed this position.

129) Id. at 94.9 .

130) Id. at 94.15 .

131) Id. at 9 4.16. This argument is completely analogical to the one made by Zaire in Am. Mfg. and Trading, Inc. v. Republic of Zaire, supra note 109.

132) Id. at $995.2,5.3$. 
has arisen in arbitration proceedings Proceeding between CMS Transmission Company and the Argentine Republic. ${ }^{133}$ In this case, the ICSID Tribunal held that such a clause authorizes a State to take whatever measures it deems necessary to protect its security interests without requesting the views of any court. However, the Tribunal added that the clause is not a self-judging clause because the legitimacy of a measure taken pursuant to such a clause may be challenged in an international tribunal, which would have jurisdiction. ${ }^{134}$

Thus although the security exception in the GATT regime creates a liabilityfree space within which trade rules would be suspended to enable a State to pursue a national security agenda without attracting responsibility for violating the rules of the trading regime, in the Proceeding between CMS Transmission Company and the Argentine Republic, the arbitrators decided a measure taken pursuant to this clause would be subject to international jurisdiction. Here the arbitration panel declined to agree with Argentina that Argentina should be allowed, consistent with U.S. practice, to construe its national security interests in the investment regime without having its decision reviewed by international tribunals. Thus in the trade regime, States arguably have more space to invoke the exception to advance their war agenda without attracting legal responsibility for departing from their trade obligations if they decide to do so. ${ }^{135}$ That is why such a broad reading of Article 21 has generated much debate and opposition in the World Trade Organization (WTO) regime. This is particularly so because the entire post-World War II UN Charter system was predicated on prohibiting the use of force, and yet the system nevertheless created exceptional circumstances under which the use of forcible measures was nevertheless permissible. ${ }^{36}$

In short, although rules of international trade in the post-World War II era were designed to preserve the national security of their members, even if this resulted in departures from GATT obligations, the international investment regime has gone in the opposite direction. It has imposed ever heightened respon-

133) CMS Gas Transmission Co. v. Argentine Republic, ICSID Case No. ARB/01/8 (May 12, 2005), available at http:// www.worldbank.org/icsid (follow "cases" hyperlink; then follow "List of Cases" hyperlink; then follow "Concluded Cases" hyperlink; then scroll to "CMS Gas Transmission Company v. Argentine Republic (ICSID Case No. ARB/01/8)").

134) Id. at $\mathbf{9} 373$. For further analysis see William W. Burke-White and Andreas von Staden, Investment Protection in Extraordinary Times: The Interpretation and Application of Non-Precluded Measures Provisions in Bilateral Investment Treaties, 48 Va. J. Int'l L., 307 (2008).

135) See Carl Schmit, The Nomos of the International Law of Jus Publicum Europaeum, p. 99 (G.L. Ulmen trans., 2003) (noting a "historical and structural relation between such spatial concepts of free trade, and free world economy, and the idea of a free space within which to pursue free competition and free exploitation").

136) This would, of course, include the right to self-defense. However, my point here is less the self-defense exception than that the GATT regime, although intended to promote peaceful commerce following the experience of the World War II, nevertheless permitted a zone of discretion on States to unilaterally decide when to depart from this regime of trade rules to protect their national security as they perceived it. 
sibilities on States for war destruction. Although there are differences in the substantive rules in GATT and with the typical war destruction clause that has been examined, my point is that national security in the GATT context can provide a safe harbor from attracting international legal liability. The opposite is true in the international investment context particularly as the Proceeding between CMS Transmission Company and the Argentine Republic shows. What is more, it is developing economies or capital-importing States that are more likely to be subject to the heightened obligations of State responsibility for war destruction in the investment context. In addition, as the Nicaragua case shows, escape clauses in the GATT context are more likely to benefit countries with enormous market power such as the United States.

My view is fortified by the ICJ's decision in the Case Concerning Oil Platforms (Iran v. United States). ${ }^{137}$ In that case, the United States was alleged to have violated the freedom of commerce and navigation clause contained in Article X(1) of the Treaty of Amity, Economic Relations, and Consular Rights it had signed with Iran. It was alleged to have done so by bombing and destroying Iranian Platforms. The Court held that the United States had not violated Article X(1). According to the Court, the United States could not have violated the freedom of commerce clause unless it could be shown that the platforms had directly and actually contributed to oil exports berween Iran and the United States. In addition, the Court held that ships were only protected to the extent they were actually engaged in commercial transport at the time of their destruction. ${ }^{138}$ In the Court's view, injury to potential commerce did not constitute injury to freedom of commerce. ${ }^{139}$ According to the Court, "the possibility must be entertained that [freedom of commerce] could actually be impeded as a result of acts entailed by the destruction of goods destined to be exported" but only in so far as the goods to be exported were already in existence. ${ }^{140}$ Thus, unlike in investment disputes where claimants often successfully claim both present and expected earnings from their investments, ${ }^{141}$ here the ICJ confined its findings to merely that which would have been physically lost by the bombings. It was irrelevant that the platforms were to be operational only within a "few days." 142 In this case, unlike in the Nicaragua GATT case discussed earlier, the Court rejected the U.S. argument that the bombing was necessary to protect international peace and security under Article $\mathrm{XX}(1)(\mathrm{d})$ of the Treaty. The court also rejected the U.S. counterclaim that

137) 2003 I.C.J. 90 (Nov. 6), available at http://www.icj-cij.org (follow "Cases" hyperlink; then follow "List of All Cases" hyperlink; then follow "More..." hyperlink under "1992: Oil Platforms (Islamic Republic of Iran v. United States of America)") [hereinafter Iran v. United States].

138) The Court also observed that at the time of the attacks there was a U.S. oil embargo against Iran.

139) Iran v. United States, supra note 137, at 992.

140) Id.

141) For a discussion of restitution and compensation for unlawful, tortuous, and delictual conduct, see Bishop, Crawford and Reisman, supra note 68, at $1278 \mathrm{ff}$ (for methods of valuing losses see $1331 \mathrm{ff}$ ).

142) Iran v. United States, supra note 137, at 993. 
certain attacks from Iran violated the freedom of commerce clause. Thus, although in this case the Court held against the U.S. claim that the attacks on the platforms were justifiable self-defense under the Charter, it nevertheless construed the freedom of commerce clause so narrowly ${ }^{143}$ as if the clause could not be read to protect commerce generally - "whether or not there was actually any commerce going on at the time" of the bombing. ${ }^{144}$ This decision was also inconsistent with an earlier decision in the preliminary stage of the case where the court had noted that treaty protected commerce generally and included "not merely the immediate act of purchase and sale, but also the ancillary activities integrally related to commerce." 145

The upshot of my claim here is that by using a security lens, freedom of commerce will often take a back seat. The ICJ opinions in the Nicaragua decision as well as in the Oil Platforms case are arguably made from the vantage point of security. By contrast, in the investment context, I have shown that cases involving questions of responsibility for war destruction are decided mostly from the view of protecting alien investors. The outcome of this contrasting approach to the intersection of war and commerce is often to protect the security and investment interests of developed economies and their investors at the expense of those of developing economies and their investors.

\section{From Forcible Interventions to Coercive and Unequal Economic Relations}

Briefly then, what we see here is a continuity of a structure of rules supportive of the rights of alien investors carried from the colonial past into the postcolonial present. As the public side of international law was guaranteeing the newly won right of political autonomy from colonial rule, thanks to the extension of the principle of self-determination to Africa and Asia, the continuity of rules of international economic governance oversaw continuity from the past to the present of colonial economic relations. For example, postcolonial countries in which there was European settlement were required as a condition of the grant of its independence by its former colonial power to guarantee white European settlers property and citizenship rights as well. ${ }^{146}$ Paradoxically, the acquisition of the autonomy by the new States became the new basis on which unequal and inegalitarian relation-

143) See Iran v. United States (Al-Khasawheh, dissenting; Elarany, dissenting; Simma, separate opinion) supra note 137.

144) Separate Opinion of Judge Simma id. at 9 3.6. Notably the court's interpretation also excluded commerce with third parties other than the two contracting parties. Yet, Article VIII of the treaty seemed to contemplate such a broader view of commerce. That clause provided that in part that the treaty was intended to cover "products of the other High Contracting Party, from whatever place and by whatever type of carrier... by whatever route."

145) Iran v. United States, Preliminary Objections, 1996 I.C.J. Rep. at 9819.

146) In the Kenyan case, see Gary Wasserman, 'The Independence Bargain: Kenya Europeans and the Land Issue, 1960-62', 11 J. Commonwealth Pol. Stud. 99-120 (1973). 
ships of international economic governance would be played out. After all, these new States were required to play by exactly the same rules that applied to the older States.

This in turn made possible the continuities of rules and obligations from the colonial past to the postcolonial present and exemplifies international law's role as "a systematic regime of accumulation" 147 in favor of rich multinational corporations with their third world allies. Conquest legitimized acquisition of territory and how colonial courts used conquest to legitimize these acquisitions of territory and those that had not been acquired by treaty or conquest. If law was central to legitimizing public and private acquisitions of territory and their subsequent exploitation, then postcolonial rules of international economic governance are not any different. In this sense, rules of international economic governance seem less given than the result of the political economy of extraction and exploitation of wealth in Africa.

In this sense, rules of international economic law were as much a reflection of the exploitative nature of colonial interests as they once were of the intellectual strength of Europe. This strength dominated the doctrines and rules that governed relations between the West and non-West politically, legally, and economically. ${ }^{148}$ From this perspective, these rules and doctrines could not immediately be expected to inaugurate a new era of equality that reversed what had become hardened and deepened rules of international economic governance. Capital-exporting States, of course, were using their intellectual strength to strenuously defend these rules by rejecting efforts to revise them.

From this vantage point, rules of international economic law then may be regarded as a set of assumptions and limitations that set the terms on which powerful and less powerful countries relate. These set of assumptions and limitations were, and continue to be based on assumptions of the superiority of Europe and the United States. The reverse is also true - the presumed inferiority of non-Europeans who lacked the technology, sophistication, and material progress that was argued to be possible only by virtue of commerce. International economic law is also a realm of specialized and privileged knowledge, such as in the arbitration proceedings involving host States and multinational investors. My contention is that this body of specialized knowledge primarily defined the prerogatives of the former colonial powers and their business interests. Repeated efforts to counter and challenge this knowledge in each round of postcolonial skirmish from the nineteenth century to the present has not made much progress in loosening the hardened rules.

147) Edward Said, Orientalism (1979) p. 123. This is also the thesis in Ugo Mattei and Laura Nader, Plunder: When the Rule of Law is Illegal (2008) (arguing that colonial relationships are now embodied in contemporary legal doctrines and approaches to economic reform including neoliberalism).

148) See James Gathii, 'International Law and Eurocentricity', 9(1) Eur. J. Int'l L. 184-21 1 (1998). 
This hardening has been justified as necessary because of the dangerous investment area the developing world continues to be. In other words, alien investors need all the protection necessary against the fragile investment climate resulting from chaos, disorder, war, and nationalization that characterizes these countries. Resistance to changing these rules therefore frequently invokes the very images of disorder and war that in the first place justified colonial conquest and the very inauguration of rules of international economic law in both the nineteenth-century Calvo clause era, as well as in the post-World War II era. To date, rules of international economic governance continue to be presented as effortlessly managing disorder in each period.

Just as rules of international law of the nineteenth century created consent for non-sovereign non-European entities to enable them to enter into treaties disposing of their territory with no other rights attached, international law today has created a sphere of rules allowing capital-importing States to be sued as private actors when they participate in market transactions without regard to whether the commercial transactions they engaged in were an exercise of a regulatory authority, rather than merely of commercial nature. ${ }^{149}$ Thus, like colonial international law, contemporary international law rules such as the restrictive theory of immunity have stripped developing countries of their sovereign immunity and given private actors the right to sue and recover against third-world States in the courts of the developed world and in arbitral forums. ${ }^{150}$ In addition, rules of international law such as the act of state and comity doctrines that were used by colonial governments to preclude judicial inquiry into their overseas conduct are now unavailable to defend capital-importing States when the exercise of the regulatory authority intersects with investor rights. ${ }^{151}$ In short, rules of international law have hollowed out the sovereignty of capital-importing States when they engage in transnational commercial activity. This means that, even if a capital-importing State seeks to defend its inability to meet a commercial obligation because of its role as a State superseded its contractual obligations, courts in first world countries would more likely still hold it liable. ${ }^{152}$ In the international investment context with regard to State responsibility for war destruction, no case illustrates this point better than the AAPL v. Sri Lanka.

149) For an extensive analysis, see James Gathii, 'The Sanctity of Sovereign Loan Contracts and Its Origins in Enforcement Litigation', 38 Geo. Wash. Int'l L. Rev. 251 (2006). See also Robert Wai, 'The Commercial Activity Exception to Sovereign Immunity and the Boundaries of Contemporary International Legalism', in C. Scott (Ed.), Torture as Tort: Comparative Perspectives on the Development of Transnational Human Rights Litigation (2001) p. 213.

150) James Gathii, 'The Sanctity of Sovereign Loan Contracts and Its Origins in Enforcement Litigation', 38 Geo. Wash. Int'l L. Rev. 251 (2006).

15i) Id.

152) See Commercial Bank of Kuwait $v$. Rifidian Bank and Central Bank of Iraq, where the Second Circuir held that a default occasioned by war, economic sanctions and the freezing of its assets making it impossible to obtain foreign currency to repay its debts did not preclude it from finding that Iraq had willfully defaulted, 15 F.3d 238, 242-43 (2d Cir. 1994). 


\section{Conclusions}

At the end of the nineteenth century and the beginning of the twentieth century, the move toward institutions, such as arbitration forums, and rules as an alternative to the use of force gave new impetus to the growth of international commercial law and related institutions. These rules and institutions represented the hope that the use of force would be eclipsed as the world moved forward toward more cooperative, consensual, and noncoercive mechanisms of dispute settlement. In the nineteenth century, the capital-importing States in Latin America became acurely aware that these institutions and rules did not completely erase the coercive and uneven relations they had with capital-exporting States. In era after era of reformism from the Calvo era, to the NIEO and to the era in opposition to neoliberal economic governance, capital-importing States have had to contend with the coercive realities of the rules of international economic governance.

As such, although the rules and institutions of international economic governance have created possibilities and alternatives to the use of force in the economic relations between capital-importing and capital-exporting States, these rules have nevertheless not completely eliminated the power of capital-exporting States to influence the content and meaning of these rules. ${ }^{153}$ Contrary to what international lawyers of the early twentieth-century thought, these rules did not entirely represent a clean break from the coercive past. Instead, these rules and institutions in many ways repackaged the inequalities between capital-exporting and capital-importing States. In a variety of ways, these rules continue to perpetuate the subordinate position of these formerly colonial countries in a manner that uncannily reflects the imbalances that characterized colonial rule.

Although the denouement of forcible measures to resolve contract debt was overstated by early twentieth-century international lawyers, international law nevertheless provided avenues for dispute settlement outside the use of force in international commercial relations. The challenge for lawyers from non-Western capital-importing States therefore became whether their advocacy for revising these rules to accommodate the interests of their countries would be accepted as legitimate demands for the revision of international law. By contrast, for the most part, international lawyers of the capital-exporting States and their governments

153) Susan Strange refers to this ability to set "the rules of the game" as structural power See Conversation with Susan Strange, available at http://www.geocities.com/jtrevin041/STRANGE.DOC (last visited June 4, 2003). Note, she gives the following example of the exercise of structural power: "An individual like the Pope has structural power because he manages the Catholic Church, and the Catholic Church, for example, prevents some Catholics from contraception or abortion in their range of options; so he is exercising structural power." Id. Further, she argues that it is "only by looking at the structural power exercised - often unconsciously - over other states, markets, private individuals, and firms by the agencies of the United States can the extent of the asymmetries of state power be appreciated." Susan Strange, "The Defective State', 124 Daedulus 55, 64 (1995). 
denounced the agenda of the NIEO as an illegitimate effort to exercise sovereignty over economic affairs whereas sovereignty was merely a political doctrine. ${ }^{154}$

I want to note in concluding that, although undemocratic capital-importing States fear loss of whatever economic sovereignty they have, rules of international investment law enable them to have access to foreign capital and investment without domestic democratic oversight. As such, the contractual nature of engaging in foreign investment decisions is often rife with corruption within capitalimporting States. ${ }^{155}$ This combination of especially friendly pro-investor rules and corruption undermines the promise of foreign investment to contribute to increased productivity. ${ }^{156}$ Such outcomes are even worse off in mineral-rich, war-torn, least-developed African countries that continue to attract increased amounts of foreign direct investment ${ }^{157}$ and the accompanying human tragedy these wars result in.

154) See e.g., Norbett Horn, 'Normative Problems of a New International Economic Order', 16 J World Trade L. 343 (1982)

155) In World Duty Free Co. Ltd. $\nu$. The Republic of Kenya (ICSID Case No. ARB/00/7) Award, Oct. 4, 2006, the arbitration tribunal was presented with convincing evidence of payment of a cash bribe to the then sitting head of state to procure a contract. The tribunal held that the contract was legally unenforceable because it was an affront to the public conscience.

156) See Kenneth J. Vandevelde, 'The Economics of Bilateral Investment Treaties', 41 Haru. J. Int'l L. 469 (2000) (arguing that BITs are inefficient in promoting foreign investment because they focus on "controlling and protecting the desired investment flow rather than on maximizing productivity through market allocations of capital," id. at 491.). Vandavelde argues that BITs merely "shift control of an asset from a local investor to a foreign investor without increasing the productive capacity of the asset" and this is occurs because these investors are more interested in controlling the movement of the capital rather than it's the promotion of its movement, id. at 492.

157) United Nations Conference on Trade and Development (UNCTAD), World Investment Report 2001: Promoting Linkages (2001). This trend has continued because of the boom in natural resources in recent times, see UNCTAD, World Investment Report: FDI from Developing and Transition Economies - Implications for Development (2006). However as a share of global FDI flows, least-developed countries still receive a miniscule percentage. 